\title{
Chapter 22 \\ Implementation of Japanese Blue Carbon Offset Crediting Projects
}

\author{
Tomohiro Kuwae, Satoru Yoshihara, Fujiyo Suehiro, and Yoshihisa Sugimura
}

\begin{abstract}
The term "blue carbon" is still rather new, having been coined in 2009. However, the blue carbon concept and the role of blue carbon stored in shallow coastal ecosystems, as part of nature-based or green infrastructure, in mitigating climate change and providing other ecosystems services, such as disaster risk reduction, infrastructure resilience, erosion control, and land formation, have attracted the interest of many people worldwide. In this chapter, we first summarize the current status of blue carbon initiatives, including for carbon offsetting, worldwide. Then, we review three blue carbon offset credit projects that have already been implemented in Japan: (1) the blue carbon offset crediting projects of (1) Yokohama City, the first in the world; (2) Fukuoka City, the second such project in Japan; and (3) the first Japanese national governmental demonstration project. Finally, we discuss the need to accelerate the development of blue carbon offset credit projects and related initiatives in the future.
\end{abstract}

Keywords Climate change $\cdot$ Blue economy $\cdot$ Blue finance $\cdot$ Nature-based solutions $(\mathrm{NbS}) \cdot \mathrm{J}$-Blue Credit

\footnotetext{
T. Kuwae $(\bowtie)$

Coastal and Estuarine Environment Research Group, Port and Airport Research Institute,

Yokosuka, Japan

Japan Blue Economy Association (JBE), Yokosuka, Japan

e-mail:kuwae@p.mpat.go.jp

S. Yoshihara $\cdot$ F. Suehiro

Environmental Planning Department, Yachiyo Engineering Co., Ltd, Tokyo, Japan

\section{Y. Sugimura}

Department of Joint Research on Environment \& Disaster in Coastal and Port Areas, Faculty of

Engineering, Kyushu University, Fukuoka, Japan
} 


\subsection{Introduction}

Nature-based or green-gray infrastructure combines conservation or restoration of ecosystems with the selective use of conventional engineering approaches to deliver climate change resilience and adaptation benefits. Green-gray approaches strategically blend "green" natural and working landscapes and other open spaces that conserve ecosystem functions and values with "gray" human-engineered technology. The utilization of coastal green-gray (also termed "blue" or "natural") infrastructure is attracting increasing attention from a policy perspective (SuttonGrier et al. 2015; World Bank 2017). Shallow coastal ecosystems (SCEs), for example, mangroves, tidal marshes, seagrass meadows, and macroalgal beds, through their role as part of the global carbon cycle and as a natural defense against external climate factors such as sea-level rise and storm surges, are a good example of green-gray infrastructure (Kuwae and Crooks 2021).

In a report jointly published in 2009 by the United Nations Environment Programme Planning Unit (UNEP), the United Nations Food and Agriculture Organization (FAO), and the United Nations Educational, Scientific, and Cultural Organization (UNESCO) (Nellemann et al. 2009), "blue carbon" is defined as carbon captured by marine organisms. The ocean is a particularly important carbon reservoir because blue carbon stored in seafloor sediments can remain undecomposed and unmineralized for long periods of time (up to several thousand years). It is estimated that 186 million tons (Kuwae and Hori 2019) (Fig. 22.1) to 238 million tons (Nellemann et al. 2009) of carbon are annually buried beneath the seafloor, and SCEs account for about 73-79\% of this carbon. This role of blue carbon in SCEs as a climate mitigation measure has attracted the interest of many people worldwide. Typical SCEs, including mangroves, tidal marshes, and seagrass meadows, are now being called "blue carbon ecosystems" (Macreadie et al. 2019).

Blue carbon initiatives are currently moving from the advocacy stage to social penetration, policy-making, and implementation stages (International Partnership for Blue Carbon; https://bluecarbonpartnership.org/). About 20\% of the countries that have joined the Paris Agreement have pledged to use SCEs as a climate change mitigation option in their nationally determined contributions (NDCs), and these countries are moving toward measuring national blue carbon amounts and accounting for them in their greenhouse gas inventories. About $40 \%$ of those countries have pledged to use SCEs to adapt to climate change as part of conservation, protection, and reforestation initiatives and through planning efforts such as Integrated Coastal Zone Management and fisheries management (Herr and Landis 2016; Martin et al. 2016). Australia (Kelleway et al. 2017) and the United States (Crooks et al. 2018) have also begun including blue carbon in their numerical emissions reduction targets and have started to calculate blue carbon in accordance with the 2013 Supplement to the 2006 United Nations Intergovernmental Panel on Climate Change (IPCC) Guidelines for National Greenhouse Gas Inventories: Wetlands (Wetlands Supplement) (IPCC 2014). The Conference of the Parties (COP) 25 to the United Nations Framework Convention on Climate Change (UNFCCC), held in Spain in 


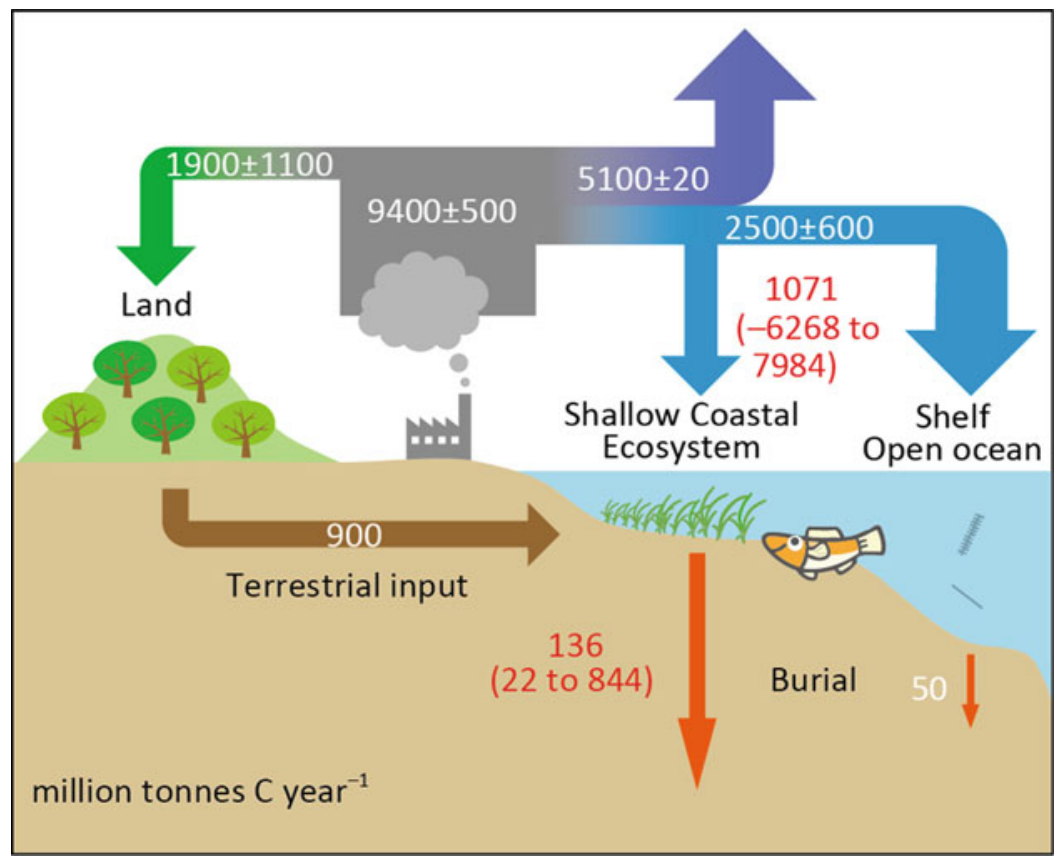

Fig. 22.1 Global carbon cycling (modified from Kuwae and Hori 2019). Data for the blue carbon sink potential (red type, showing mean and range) are from Kuwae and Hori (2019); atmospheric data (mean \pm SD for 2010-2019) are from Friedlingstein et al. (2020); and terrestrial input data are from IPCC (2013)

2019, was positioned as a "Blue COP," and the importance of the ocean as part of the global climate system was mentioned for the first time in the COP-adopted document.

In conjunction with these international efforts, local communities have begun to recognize the importance of blue carbon and efforts toward its social implementation. Private companies, regional administrative organizations, and individual managers and engineers have expressed a strong interest in future socioeconomic development that incorporates the conservation or restoration of blue carbon ecosystems as new business opportunities (Thomas 2014; Nobutoki et al. 2019). In this context, Japan has clearly stated its intention to pursue the potential of blue carbon as a carbon dioxide $\left(\mathrm{CO}_{2}\right)$ sink in the "Long-Term Strategy as a Growth Strategy Based on the Paris Agreement," approved by the Cabinet in 2019. Other countries have also developed policy frameworks and conducted case studies related to blue carbon (e.g., Laffoley and Grimsditch 2009; Crooks et al. 2011; Lutz et al. 2014; Wylie et al. 2016; EX-ACT 2017; Howard et al. 2017; Villa and Bernal 2018; Wyndham-Meyers et al. 2018).

One of the most efficient and effective ways of promoting climate change mitigation is to implement emissions trading systems (ETS). The two main types of 
ETS are "cap-and-trade" and "baseline-and-credit." Cap-and-trade systems impose a cap on aggregate emissions levels but allow trades of allowances between covered entities. Baseline-and-credit systems define an emission baseline and reward verified emission reductions beyond that baseline with tradable offset credits. Offset credits, as an incentive for climate change mitigation, are well established for forest and agricultural ecosystems, and several voluntary carbon markets have certified blue carbon offset methodologies and implementation protocols (Kelleway et al. 2020; Sapkota and White 2020).

In this chapter, we first outline three blue carbon offset credit projects that have already been socially implemented in Japan: the blue carbon offset credit projects of (1) Yokohama City, the world's first, and (2) of Fukuoka City, the second such project in Japan, and (3) the first Japanese national governmental demonstration project (Table 22.1). Second, we review the challenges encountered in implementing these projects in terms of people, goods, money, and mechanisms and how they were solved. Finally, we discuss issues and directions for future project expansion.

\subsection{Carbon Offset Credits}

The socioeconomic aims of blue carbon initiatives include improving the capital value and economic benefits of SCEs and their cost-effectiveness as public works, as well as promoting local business (Thomas 2014). These benefits referred to here include economic incentives, including carbon offset credits (carbon trading), payments for ecosystem services, and income from funds (Murray et al. 2011; Herr et al. 2015).

There are at present two types of carbon trading markets: voluntary markets and compliance markets. Voluntary markets have been developed to credit actions taken to reduce greenhouse gas emissions, primarily by private sector companies, to reduce a company's environmental footprint, to demonstrate corporate social responsibility, and to enhance public relations. Compliance markets, which deal with mandatory emission reductions imposed by regulations, are driven by the demand for allowances and offsets by regulated greenhouse gas emitters.

Historically, carbon offset credits have been implemented by a top-down approach, in which international markets are first established and credit markets at the national and local government levels are subsequently created. However, in the new framework adopted at COP 21 in 2015, which is legally binding after 2020 as part of the Paris Agreement, mitigation measures are undertaken in a unique way by each country, and a mutual verification mechanism (i.e., the pledge and review approach) is the basic policy. Thus, to implement the new policy of the Paris Agreement, both global and local climate change countermeasures will be promoted. Also, the use of monetary incentives to appeal to the private sector requires a bottom-up approach, in which markets are newly established at the local governmental level, as we describe in this chapter, and privately led projects are developed. 
Table 22.1 Current blue carbon (BC) credit schemes in Japan

\begin{tabular}{|c|c|c|c|c|}
\hline & & Yokohama BC Credit & Fukuoka BC Credit & J-Blue Credit \\
\hline Year established & & 2015 & 2019 & 2021 \\
\hline Carbon market & & Voluntary & Voluntary & $\begin{array}{l}\text { Voluntary, but } \\
\text { also compliance } \\
\text { targeted }\end{array}$ \\
\hline $\begin{array}{l}\text { Developer and } \\
\text { secretariat }\end{array}$ & & $\begin{array}{l}\text { Yokohama } \\
\text { city }\end{array}$ & $\begin{array}{l}\text { Fukuoka } \\
\text { city }\end{array}$ & $\begin{array}{l}\text { Japan Blue } \\
\text { Economy } \\
\text { Association } \\
\text { (JBE) approved } \\
\text { by the Japanese } \\
\text { government }\end{array}$ \\
\hline $\begin{array}{l}\text { Validation and } \\
\text { verification body } \\
\text { (VVB) }\end{array}$ & & $\begin{array}{l}\text { Not } \\
\text { established }\end{array}$ & $\begin{array}{l}\text { Not } \\
\text { established }\end{array}$ & $\begin{array}{l}\text { Established with } \\
\text { members } \\
\text { independent of } \\
\text { the secretariat } \\
\text { (JBE) }\end{array}$ \\
\hline Approver & & $\begin{array}{l}\text { Yokohama } \\
\text { City }\end{array}$ & $\begin{array}{l}\text { Fukuoka } \\
\text { City }\end{array}$ & JBE \\
\hline Spatial coverage & & $\begin{array}{l}\text { Within } \\
\text { Yokohama } \\
\text { City and } \\
\text { some } \\
\text { collaborating } \\
\text { local } \\
\text { governments }\end{array}$ & $\begin{array}{l}\text { Within } \\
\text { Fukuoka } \\
\text { City }\end{array}$ & Nationwide \\
\hline $\begin{array}{l}\text { Inclusion into } \\
\text { national } \\
\text { accounting }\end{array}$ & & Not yet & Not yet & $\begin{array}{l}\text { Targeted by } \\
2023\end{array}$ \\
\hline $\begin{array}{l}\text { Inclusion into } \\
\text { national } \\
\text { emission trading } \\
\text { systems (ETS) }\end{array}$ & & Not yet & Not yet & $\begin{array}{l}\text { Targeted by } \\
2025\end{array}$ \\
\hline \multirow[t]{4}{*}{ Project activities } & $\begin{array}{l}\text { BC sink } \\
\text { creation/ } \\
\text { restoration/ } \\
\text { conservation } \\
\text { (IPCC } \\
\text { methodology } \\
\text { applied) }^{\mathrm{a}}\end{array}$ & $\begin{array}{l}\text { Seagrass (Tier } \\
\text { 1) }\end{array}$ & $\begin{array}{l}\text { Seagrass } \\
\text { (Tier 3) }\end{array}$ & Seagrass (Tier 3) \\
\hline & & $\begin{array}{l}\text { Macroalgal } \\
\text { beds (N/A) }\end{array}$ & & $\begin{array}{l}\text { Macroalgal beds } \\
\text { (N/A) }\end{array}$ \\
\hline & & & & $\begin{array}{l}\text { Salt marshes and } \\
\text { tidal flats (Tier } \\
\text { 1) }\end{array}$ \\
\hline & $\begin{array}{l}\mathrm{CO}_{2} \text { emission } \\
\text { reduction }\end{array}$ & Yes $^{b}$ & Not yet & Not yet \\
\hline Trading price & & $\begin{array}{l}8000 \text { yen/ton } \\
\mathrm{CO}_{2}\end{array}$ & $\begin{array}{l}8000 \text { yen/ton } \\
\mathrm{CO}_{2}\end{array}$ & $\begin{array}{l}\text { Negotiated } \\
\text { transaction }\end{array}$ \\
\hline
\end{tabular}

${ }^{\text {a }}$ See IPCC (2014)

${ }^{\mathrm{b}}$ See Nobutoki et al. (2019) 
For the social implementation of carbon credit schemes, independent methods for the measurement, reporting, and verification (MRV) of credits are needed. These methods involve accurate, objective, and quantitative measurement of carbon based on scientific and technological knowledge, transparent reporting, and verification. The submission of greenhouse gas inventories to the UNFCCC Convention Secretariat is based on the MRV principle.

Mitigation of climate change by storing atmospheric $\mathrm{CO}_{2}$ in the sea via natural systems can be achieved by three approaches: (1) newly creating target ecosystems (i.e., carbon reservoirs and atmospheric $\mathrm{CO}_{2}$ sinks), (2) reducing the decline of target ecosystems through restoration and conservation, and (3) improving the management of target environments and ecosystems (i.e., improving carbon storage rates and the $\mathrm{CO}_{2}$ uptake rate per unit area).

Various guidelines for measuring carbon storage and $\mathrm{CO}_{2}$ uptake by blue carbon ecosystems and for creating credits for blue carbon have been developed. Australia has included blue carbon ecosystems in its national greenhouse gas accounts, and the Australian Government's Emissions Reduction Fund has developed comprehensive guidelines (Kelleway et al. 2017). Other organizations that have produced guidelines include the IPCC (IPCC 2014), Conservation International, UNESCO, the International Union for Conservation of Nature (Howard et al. 2014), UNEP and the Center for International Forestry Research (Crooks et al. 2014), and the Verified Carbon Standard (2015), which is an independent carbon trading certification body in the United States. In Japan, guidance documents describing measurement methods for seagrass meadows, tidal flats, embayments, and port facilities have been prepared (Tokoro et al. 2015).

\subsection{Offset Crediting by the Yokohama Blue Carbon Project}

\subsubsection{Background}

In the Yokohama City Action Plan for Global Warming Countermeasures, the city of Yokohama, Japan, has set a target of reducing greenhouse gas emissions by $7 \%$ by 2021 and by $30 \%$ by 2030, compared to 2013 levels. Yokohama City is a member of the C40 Cities Climate Leadership Group (C40; https://www.c40.org/) and the Local Governments for Sustainability (ICLEI; https://www.iclei.org), which are international networks of cities that are actively working to combat climate change. In addition, it was selected as the only Asian member of the Carbon Neutral Cities Alliance (CNCA; https//carbonneutralcities.org) in 2015.

The Yokohama Blue Carbon Project, started in 2014, aims to create a variety of synergistic effects between the environment (e.g., through water purification, biodiversity conservation), society (e.g., through enhancement of amenities and the Yokohama brand), and the economy (e.g., by increasing supplies of resources and food, and increasing tourism), by implementing global warming countermeasures 


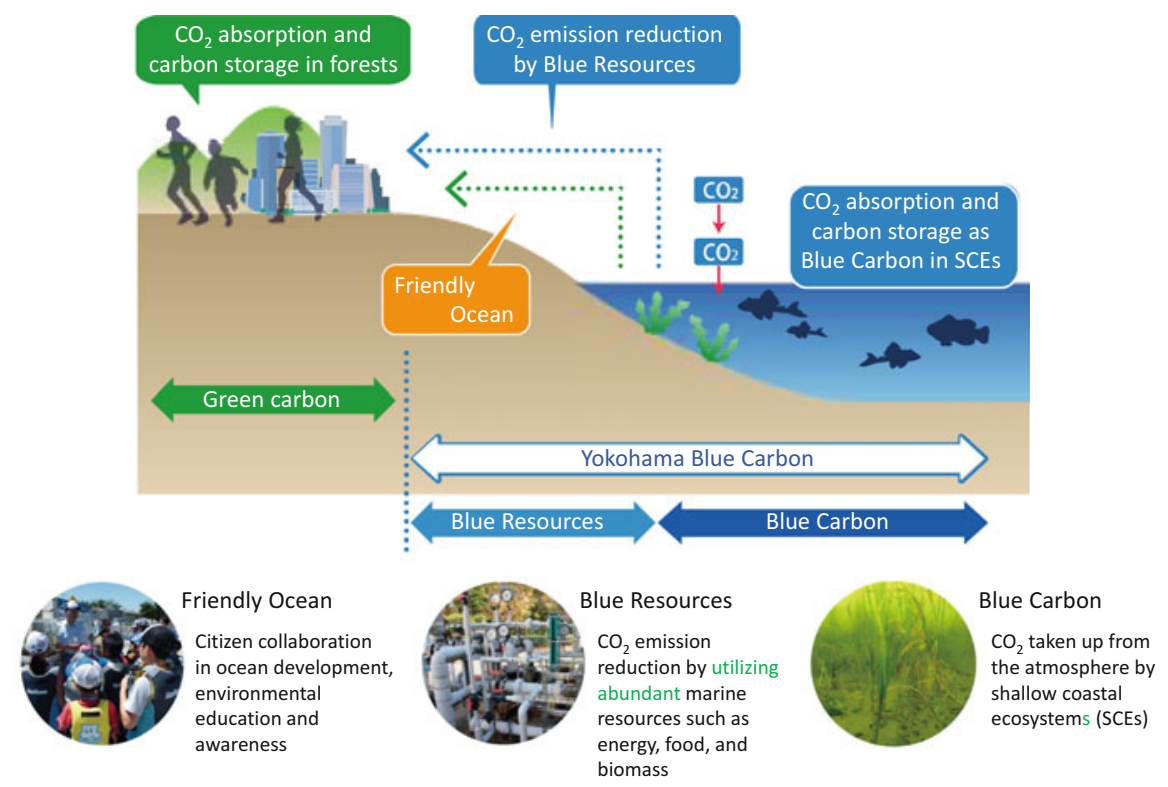

Fig. 22.2 Framework of the Yokohama Blue Carbon Project (modified from Suehiro et al. 2020)

(Nobutoki et al. 2019). In addition to "blue carbon," which refers to the utilization of SCEs as $\mathrm{CO}_{2}$ sinks, this project introduced the concept of "blue resources," which are resources tailored for effective utilization of the abundant marine energy, food, and biomass resources for $\mathrm{CO}_{2}$ emission reduction (Fig. 22.2). Furthermore, the project employs the "Friendly Ocean" concept to promote citizen collaboration in ocean development, environmental education, and environmental awareness.

The Yokohama Blue Carbon Project certifies the amounts of greenhouse gas absorption and reduction by blue carbon or blue resources as blue carbon credits and promotes carbon offsetting by trading these credits. Since the project's initiation in 2014, the amounts of credits created (Table 22.2) and used (Table 22.3), as well as the number of users, have been increasing each year (Suehiro et al. 2020). Although social penetration by this scheme has been gradually increasing, all of these credits were from blue resources until 2018. Therefore, in 2019, Yokohama City introduced the certification and offsetting of blue carbon credits to revitalize the project.

\subsubsection{Calculation Methodology}

The blue carbon offset credit scheme is based on both the IPCC Guidelines (IPCC 2014), which outline methodologies for calculating the $\mathrm{CO}_{2}$ sink capacity of blue carbon ecosystems (mangroves, tidal marshes, and seagrass meadows), and on methodologies described by Kuwae et al. (2019). The methodologies of Kuwae et 


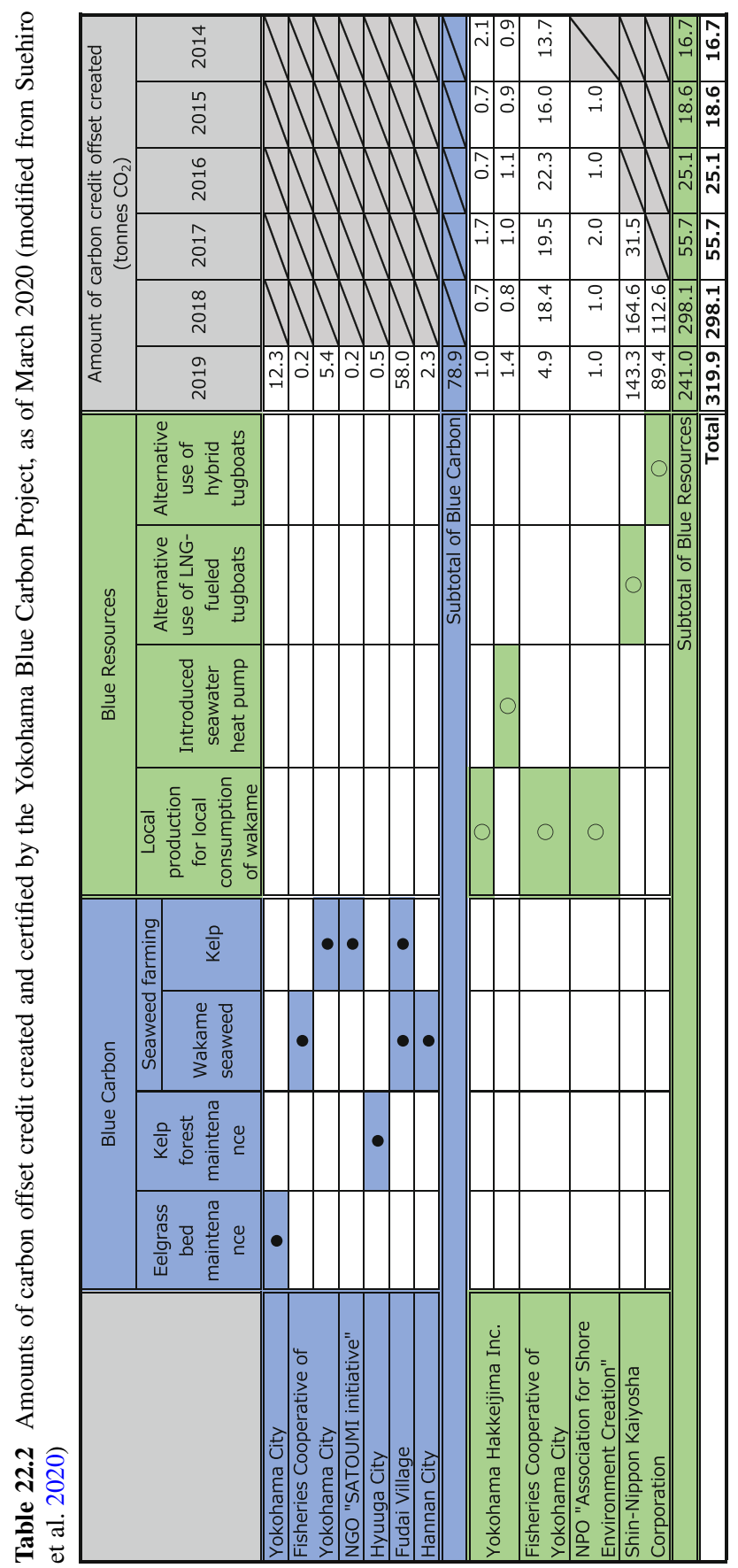


Table 22.3 Amounts of carbon offset credit used by the Yokohama Blue Carbon Project, as of March 2020 (modified from Suehiro et al. 2020)

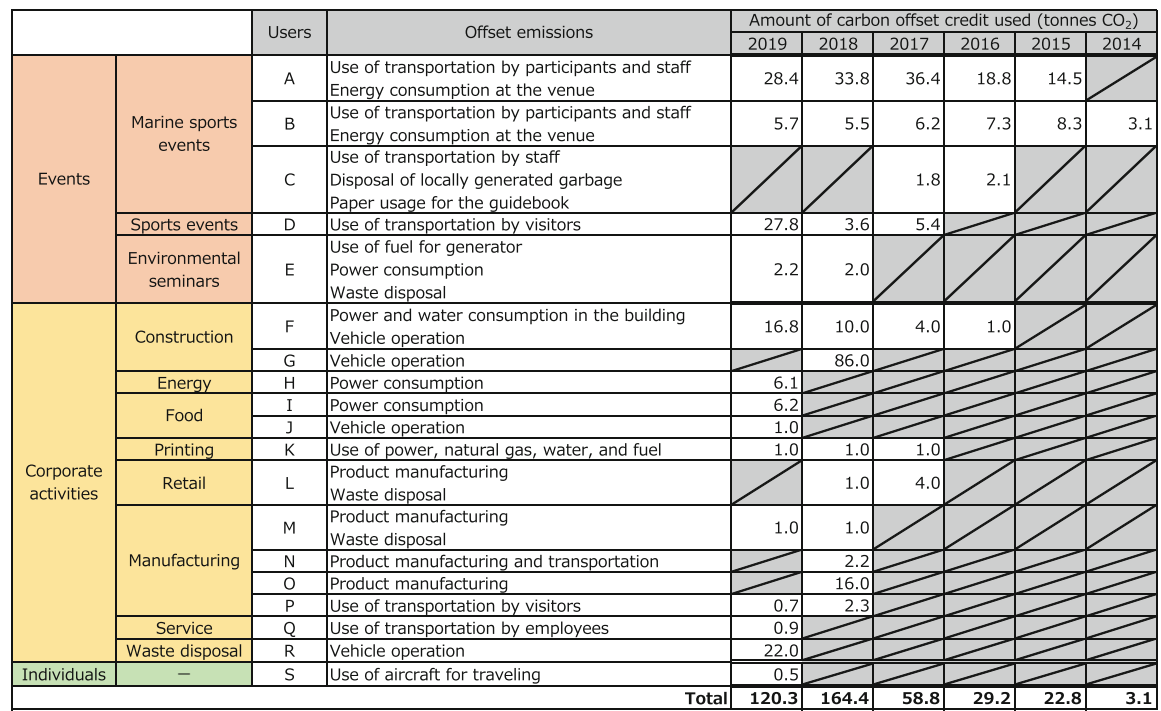

al. (2019) are based on compilations of domestic and international data, and while in line with the IPCC Guidelines (IPCC 2014), they can be used to estimate the $\mathrm{CO}_{2}$ sink capacities of macroalgal beds and tidal flats as well as those of other blue carbon ecosystems throughout Japan. Although this scheme is, in a sense, a social experiment and unique to Yokohama City, to the best of our knowledge, it is the first project in the world that credits the $\mathrm{CO}_{2}$ sink capacities of seagrass meadows, macroalgal beds, and seaweed aquaculture.

Both the IPCC Guidelines (IPCC 2014) and Kuwae et al. (2019) calculate the $\mathrm{CO}_{2}$ sink capacity of an SCE as the product of the area (ha) of the target ecosystem (referred to as "activity data") and the amount of $\mathrm{CO}_{2}$ absorbed per unit area (removal coefficient):

$$
\begin{aligned}
& \text { Annual } \mathrm{CO}_{2} \text { sink capacity (tons } \mathrm{CO}_{2} / \text { year) } \\
& =\text { activity data (ha) } \times \text { removal coefficient (tons } \mathrm{CO}_{2} / \text { ha/year) }
\end{aligned}
$$

The default (Tier 1) value (1.58 tons $\mathrm{CO}_{2} /$ ha/year) in the IPCC Guidelines (IPCC 2014) was used as the removal coefficient for eelgrass beds (Zostera marina), and removal coefficients estimated by Kuwae et al. (2019) were used for macroalgal beds [Sargassum, 2.7 tons $\mathrm{CO}_{2} /$ ha/year; wakame and arame kelps (Undaria, Ecklonia, and Eisenia), 4.2 tons $\mathrm{CO}_{2} /$ ha/year]. The $\mathrm{CO}_{2}$ sink capacity of seaweed farms was calculated as the product of the net primary production of the seaweeds and the residual rate (the percentage of net primary production that is 
stored for a long period in the ocean carbon pool without reverting to $\left.\mathrm{CO}_{2}\right)(\mathrm{Kuwae}$ et al. 2019):

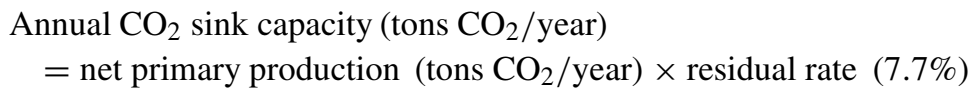

\subsubsection{Implementation}

Equation (1) was used to calculate the $\mathrm{CO}_{2}$ sink capacity in 2019 of the eelgrass beds maintained and managed at Sea Park Yokohama $\left(35.3394^{\circ} \mathrm{N}, 139.6360^{\circ} \mathrm{E}\right)$. The distribution area of eelgrass was determined by conducting a GPS logger survey during the eelgrass blooming season in June 2019 and using location information provided by park managers. The recorded area was 7.8 ha, and the estimated $\mathrm{CO}_{2}$ sink capacity of the eelgrass beds was 12.3 tons $\mathrm{CO}_{2}$ /year, and the certified credit amount was 12.3 tons $\mathrm{CO}_{2}$ (Table 22.2).

Equation (2) was used to calculate the $\mathrm{CO}_{2}$ sink capacity of the wakame (Undaria) cultivated (22.8 tons wet weight) by the Kanazawa Branch of the Yokohama City Fisheries Cooperative Association $\left(35.3312^{\circ} \mathrm{N}, 139.6375^{\circ} \mathrm{E}\right)$ in 2019. The estimated $\mathrm{CO}_{2}$ sink capacity was 0.2 tons $\mathrm{CO}_{2} /$ year, and the certified credit amount was also 0.2 tons $\mathrm{CO}_{2}$.

The scheme initially targeted blue carbon and blue resources within the Yokohama City area. However, increased awareness of blue carbon initiatives in Japan has led to the expansion of this scheme to other municipalities, which are collaborating with Yokohama City to further develop blue carbon offsets (Table 22.2).

The number of credit applicants and the total amount of certified credits for blue resources have been increasing each year. In 2017, Yokohama City established a methodology for calculating reductions in $\mathrm{CO}_{2}$ emissions achieved by replacing tugboats fueled by heavy oil first with LNG-fueled tugboats and then, in 2018, with hybrid tugboats. For details of the methodologies of other blue resources, see Nobutoki et al. (2019).

At the beginning of the project, the main use of the credits was to offset $\mathrm{CO}_{2}$ emissions generated by short-term events; however, by the third year (2016) of the project, credits had begun to be used to offset $\mathrm{CO}_{2}$ emissions from ongoing corporate activities (Table 22.3). Credits were used by individuals for the first time in 2019. 


\subsection{Offset Credit System of Fukuoka City}

\subsubsection{Background and Framework}

In Fukuoka City, the "Hakata Bay NEXT Conference" was established in 2018 to promote collaborations among citizens, fisheries, businesses, educators, and government in carrying out environmental, economic, and societal improvements to the rich environment of Hakata Bay in Fukuoka City to pass on to future generations (Sugimura et al. 2021). At present, the conference is working on the conservation, restoration, and utilization of the Hakata Bay environment with a focus on eelgrass bed creation. As part of these activities, a blue carbon offset credit scheme and a funding scheme that utilizes a part of ship entry fees and donations from companies as financial resources for environmental conservation and restoration activities were established (Fig. 22.3). The offset credit scheme is the second for blue carbon in

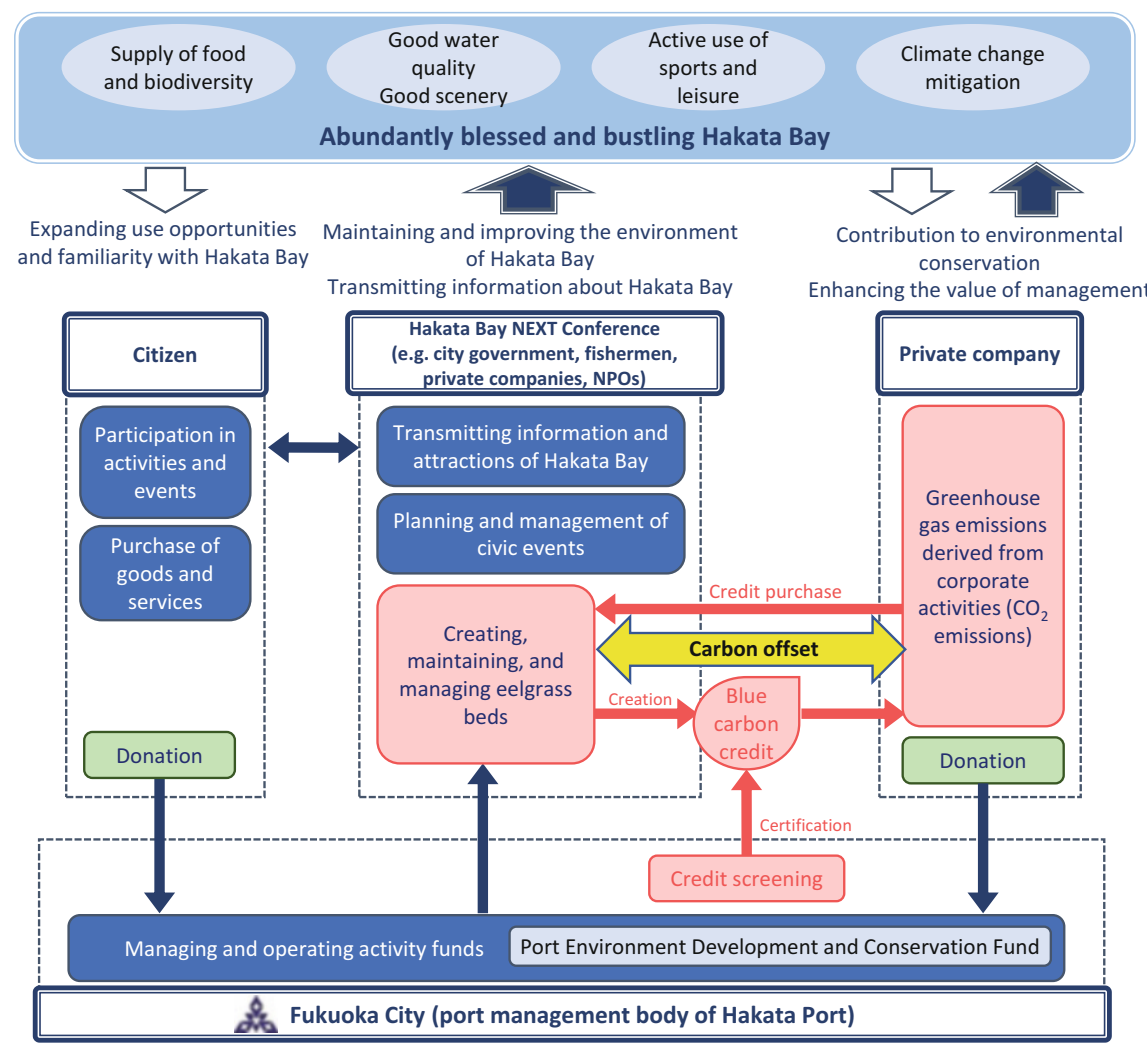

Fig. 22.3 Framework of the Fukuoka City blue carbon offset credit system (modified from Sugimura et al. 2021) 
Japan after Yokohama City, and the funding scheme is the first such scheme in the country.

In the Fukuoka City blue carbon offset credit scheme, the amount of $\mathrm{CO}_{2}$ absorbed as a result of the creation, maintenance, and management of eelgrass beds and macroalgal beds in Hakata Bay is designated as a blue carbon credit. Proceeds from the sale of credits by Fukuoka City, the project implementer, are returned to the Hakata Bay NEXT Conference to fund its environmental conservation activities, including eelgrass bed-related activities (Fig. 22.3). The funding scheme utilizes income from port operations and donations from companies and individuals for the conservation and creation of Hakata Bay environments. According to this scheme, $2.5 \%$ of port charges collected from ships, as well as donations from individuals and corporations, are used for Hakata Bay conservation and creation projects in the current fiscal year, and another $2.5 \%$ of the port charges are accumulated in the Port Environment Improvement and Conservation Fund for future projects.

\subsubsection{Carbon Offset Credit Scheme and Implementation}

The $\mathrm{CO}_{2}$ sink capacity of the target eelgrass beds at Hakata Bay was calculated as described in Sect. 22.3.2 for the Yokohama City scheme, using Eq. (1) and the methodologies in the IPCC Guidelines (IPCC 2014) and Kuwae et al. (2019). However, the Fukuoka City scheme used the modeled (Tier 3) value (2.7 tons $\mathrm{CO}_{2}$ /ha/year) for the removal coefficient of eelgrass beds. Modeled values were also used for the removal coefficients of macroalgal beds [Sargassum, 1.09 tons $\mathrm{CO}_{2}$ /ha/year; wakame kelp (Undaria), 0.45 tons $\mathrm{CO}_{2} /$ ha/year) (Sugimura et al. 2021). Both the eelgrass bed and macroalgal bed projects are considered to be eligible targets for offset credits because the former are managed beds, and intensive efforts are underway to establish the latter on new seawalls.

In an area survey conducted in May 2019, when the turbidity of seawater was relatively low in Hakata Bay $\left(33.6136^{\circ} \mathrm{N}, 130.3125^{\circ} \mathrm{E}\right)$, the total area of the eelgrass beds was estimated by generating a composite image based on aerial images obtained by a multicopter (aerial drone), visually classifying the cover classes, and then calculating the area of each cover class. The distribution area and cover class of eelgrass beds in the offshore area, which were difficult to determine from the aerial images, were corrected by using visual surveys by divers. An area survey of macroalgal beds was conducted visually by divers.

The estimated areas of eelgrass beds and macroalgal beds were 15.6 and 2.9 ha, respectively, the resulting estimated $\mathrm{CO}_{2}$ sink capacities were 42.1 and 1.3 tons $\mathrm{CO}_{2}$ /year, respectively, and the amounts of certified credits were 42.1 and 1.3 tons $\mathrm{CO}_{2}$, respectively (Sugimura et al. 2021). 


\subsubsection{Funding Scheme and Implementation}

In 2020, Fukuoka City's general budget of 38,533,000 yen included 100,000 yen for the Hakata Bay Environment Conservation and Creation Project and 3,625,000 yen (equivalent to $2.5 \%$ of port charges) for the Port Environment Improvement and Conservation Fund Reserve to be used for the Hakata Bay Environmental Conservation and Creation Project. In addition, 3,625,000 yen in port charges (equivalent to the reserved fund) and 100,000 yen in anticipated donations were budgeted for the Hakata Bay Environmental Conservation and Creation Project. Thus, $2.5 \%$ of port charges would be accumulated in the Port Environment Improvement and Conservation Fund, and another $2.5 \%$ would be used for the Hakata Bay Environmental Conservation and Creation Project during the current fiscal year. All donations would also be used for the project during the current fiscal year.

\subsection{Offset Crediting Demonstration by the Japanese National Government}

\subsubsection{Background}

In 2020, the Japanese Ministry of Land, Infrastructure, Transport and Tourism (MLIT 2020) approved the foundation of the Japan Blue Economy Association (JBE; https://www.blueeconomy.jp/en/) as a Collaborative Innovation Partnership (CIP), a type of national government-approved private cooperative. JBE is the first CIP for the marine environment in Japan. The ministry also decided to implement an offset credit demonstration project in collaboration with JBE.

A variety of the initiatives in JBE are implemented by researchers, engineers, and practitioners in different fields and positions, all of which are included on an equal footing under the supervision of the government, to promote collaboration among various partners such as private companies, municipalities, NGOs, and NPOs. JBE is developing detailed methodologies for blue economy projects based on scientific and technological evidence and quantitative evaluations of ecosystem services and their economic value. The anticipated contributions of JBE to partners include the following:

1. NPOs/NGOs: Raising national awareness of coastal environmental initiatives implemented at local sites and obtaining funding for those initiatives.

2. Private companies: Quantifying their environmental, social, and corporate governance (ESG) efforts as key performance indicators (KPIs) and, in particular, contributing to society through Sustainable Development Goal (SDG) activities, including SDG 14 (Life Below Water), SDG 13 (Climate Action), and SDG 6 (Clean Water and Sanitation). 
3. Citizens and educators: Developing and identifying methods for measuring how much $\mathrm{CO}_{2}$ is taken up by vegetation growing on shorelines in their own community.

\subsubsection{Characteristics of the Carbon Offset Scheme}

The national demonstration project and the carbon offset scheme "J-Blue Credit" are currently set up for the voluntary market, but the compliance market will also be targeted after blue carbon becomes included, similar to the "J-Credit," in the national baseline-and-credit system of Japan. JBE, as secretary of the national demonstration project, is not dependent on subsidies but is managed as an independent corporation. This makes the scheme different from those operated by local governments, as detailed below.

\subsubsection{Multiple Methodological Options}

The first difference is that JBE prepares multiple methodological options for determining removal coefficients and activity data (areas). As incentives for options that are technically difficult but result in more certain (more accurate and reliable) estimates, the amount of the credits certified is increased and transaction fees are decreased. In this way, a project as a whole can be expected to automatically improve the accuracy and reliability of the estimation methodology and achieve facility development. In contrast, negative incentives such as high fees and a small amount of credits certified are provided for options that are technically easy and thus likely to be implemented in many situations, at least in the near future.

\subsubsection{Continuous Review and Revision}

Second, established methodologies are subject to continuous review and revision by JBE, whereas the methodologies of many domestic and international credit schemes are more or less fixed. A flexible scheme in which methodologies are reviewed and revised in light of the rapid progress in science and technology (e.g., area determination using both aerial and above-water sailing drones and remote sensing) should improve certainty and reduce costs, although project management may become more burdensome.

\subsubsection{Variable Transaction Prices}

Third, dynamic pricing such as direct trading and auctions is introduced. The unit price of credit transactions is often fixed when local governments are in charge of 
the carbon offset scheme secretariat because the fixed price is apt to the secretariat to minimize the risk of failure. However, such fixed prices may not reflect the balance of supply and demand. In interviews about their reasons for purchasing blue carbon credits, buyers indicated that they appreciated or sympathized with not only climate change measures but also other co-benefits aligned with the buyer's goals and branding messages. By allowing the price to vary, these co-benefits can be reflected in the transaction price, thus increasing the unit price.

\subsubsection{Case Study}

A case study was conducted in the Yokohama Bay Side Marina $\left(35.3837^{\circ} \mathrm{N}\right.$, $\left.139.6506^{\circ} \mathrm{E}\right)$, where both eelgrass and Sargassum beds were newly created by transplantation. The offset credit scheme adopted methodologies in both the IPCC Guidelines (IPCC 2014) and Kuwae et al. (2019); thus, the $\mathrm{CO}_{2}$ sink capacity of SCEs was calculated by using Eq. (1) (see Sect. 22.3.2). From the candidate options prepared for the JBE scheme, based on the multiple option policy described in Sect. 22.5.2.1, the modeled value of 4.9 tons $\mathrm{CO}_{2} /$ ha/year was selected for the removal coefficient of the eelgrass beds and the modeled value of 2.7 tons $\mathrm{CO}_{2} /$ ha/year was selected for the Sargassum beds (Kuwae et al. 2019). An area survey of the eelgrass and Sargassum beds was conducted in March 2017. The total area of these beds was estimated by generating a composite image based on aerial images taken by a multicopter (drone), visually classifying the cover classes, and then calculating the area of each cover class.

The estimated areas were 10.3 ha for the eelgrass beds and 0.3 ha for the Sargassum beds, the resulting $\mathrm{CO}_{2}$ sink capacities were 50.2 tons $\mathrm{CO}_{2}$ /year and 0.6 tons $\mathrm{CO}_{2}$ /year, respectively, and the certified credit amounts were 22.8 tons $\mathrm{CO}_{2}$ and 22.8 tons $\mathrm{CO}_{2}$, respectively, based on the credit reduction policy that considered the uncertainty, as described in Sect. 22.5.2.1.

\subsection{Keys for Successful Implementation}

Highlights and breakthroughs in terms of mechanisms, people, goods, and money associated with the project implementations described in Sects. 22.3, 22.4, and 22.5 are summarized below. 


\subsubsection{Yokohama City}

1. Yokohama City has already implemented a number of initiatives to combat global warming in coastal areas through industry-government-academia-private partnerships.

2. Yokohama City was able to decide to establish its own scheme ahead of the rest of the world despite the incomplete scientific knowledge of blue carbon and the lack of social implementations.

3. The project was promoted in collaboration with stakeholders (scientists, engineers, consultants, and many other experts), who willingly and quickly provided the know-how for resolving the conflict between "as easy as possible" and "high certainty" schemes.

4. The use of the sea area within an aquarium as a field for a demonstration experiment was graciously agreed upon.

5. The project generated enthusiasm and energy among municipal officials.

6. The very positive attitude of the credit creators and credit users toward marine environments fitted with the objectives of this project.

7. An international fund was utilized, and the project was included in the long-term city budget.

8. The sale of credits generated a profit.

\subsubsection{Fukuoka City}

1. Fukuoka City established the Hakata Bay Environmental Conservation Plan.

2. Various entities, including private citizens and citizens' groups, fishermen, businesses, educators, and the government, have successfully worked together toward the conservation and creation of marine ecosystems.

3. A foundation has been laid for industry-government-academia-private sector cooperation.

4. The Hakata Bay NEXT Conference was established as the project's main entity.

5. New financial resources were secured through the creation of a new funding scheme utilizing port charges.

\subsubsection{National Demonstration Project}

1. Japan already had a framework of government-approved private corporations and related laws to promote industry-government-academia-private partnerships.

2. The Japanese national government has been hosting blue carbon study groups and discussion committees for several years.

3. Successful efforts by local governments have been recognized in Japan. 
4. The JBE CIP was founded, and a national demonstration project was led by people from JBE who support local government initiatives.

5. Costs for the foundation of JBE and the national demonstration project were minimized.

\subsection{Challenges for Future Blue Carbon Offset Schemes}

\subsubsection{Quantification and Reducing Uncertainty}

The accumulation of scientific and technological knowledge is still very important for connecting blue carbon initiatives to policy-making and implementation (Macreadie et al. 2019). Here, we propose four areas of blue carbon research, based on Kuwae and Hori (2019), that require further quantification relevant to carbon offset credit schemes:

1. Key data on carbon stocks and flows (primarily $\mathrm{CO}_{2}$ uptake and blue carbon storage) for various SCEs still need to be gathered by conventional methods (Kuwae et al. 2016; Crosswell et al. 2017). In particular, more continuous longterm, large-scale in situ observation data, as well as monitoring data obtained by remote sensing technologies, are needed to measure changes in the distribution areas of target ecosystems.

2. New measurement techniques need to be established for carbon stocks and flows that researchers have not been able to quantify by using conventional methods, especially seasonal fluctuation and the drifting amount of the macrophyte biomass, as well as the formation of refractory dissolved organic matter in SCEs (Wada et al. 2008; Orr 2014; Hill et al. 2015; Krause-Jensen and Duarte 2016; Duarte and Krause-Jensen 2017; Hamaguchi et al. 2018; Jiao et al. 2018; Abo et al. 2019; Ortega et al. 2019). Underlying processes and mechanisms also need to be elucidated by using the new measurement techniques.

3. The spatiotemporal variability of measured carbon stocks and flows, particularly in response to long-term disturbances such as climate change (Arias-Ortiz et al. 2018; Watanabe et al. 2019) and altered food web structures (Atwood et al. 2015), as well as short-term disturbances such as storm and tsunami events (Cahoon et al. 2003), needs to be estimated.

4. The temporal scale required for a functional response from restored SCEs needs to be evaluated (O'Connor et al. 2020; Kuwae and Crooks 2021). The importance of the temporal scale used is clear: for seagrass meadows, 10-20 years might be needed for the soil organic carbon pool or carbon accumulation rate of restored and managed sites to achieve the levels natural sites take in the case of seagrass meadows (Duarte et al. 2013; Greiner et al. 2013; Marbà et al. 2015), at least 25100 years are required but for tidal marshes (Craft et al. 2003; Burden et al. 2013), 20-25 years for mangrove wetlands (Osland et al. 2012; Salmo et al. 2013), and 7-17 years for blue carbon ecosystems generally (mangroves, tidal marshes, 
seagrass meadows) (reviewed by O'Connor et al. 2020). These temporal scales are comparable to those required for the recovery of coastal habitats (Duarte et al. 2020).

\subsubsection{Considering Emissions from SCEs}

In this chapter, we have focused only on the $\mathrm{CO}_{2}$ absorption and climate change mitigation effects of SCEs. However, $\mathrm{CO}_{2}$ emissions from SCEs are also possible, as a result of development projects and human activities such as dredging, excavation, and aquaculture (e.g., Macreadie et al. 2015; Serrano et al. 2016; Atwood et al. 2017; Kauffman et al. 2017; Lovelock et al. 2017). Thus, it is of equal importance to measure, report, and verify the reduction of carbon stocks and increase in $\mathrm{CO}_{2}$ emissions from SCEs caused by human activities for the future establishment of disincentives.

\subsubsection{Expanding the Scope of Carbon Offsetting}

Blue carbon ecosystems such as mangroves, tidal marshes, and seagrass meadows have been shown to have climate change mitigation functions and benefits (Duarte et al. 2013), but we should not limit ourselves to these ecosystems when considering ways to mitigate climate change mitigation and provide other co-benefits. The scope of blue carbon offset schemes should be broadened to include other ecosystems, known as "potential blue carbon ecosystems," which can also play important roles in climate change mitigation (Crooks et al. 2019; Hoegh-Guldberg et al. 2019; Kuwae and Hori 2019; Kuwae et al. 2019; Lovelock and Duarte 2019). For instance, tidal mudflats can be viewed, along with tidal marshes and mangroves, as a type of intertidal blue carbon ecosystem; although they lack large vegetation, their microphytobenthos can take up atmospheric $\mathrm{CO}_{2}$ and their soils can store the captured carbon. Moreover, similar coastal ecosystems and carbon storage mechanisms can be found in arid regions (e.g., microbial mat systems and coastal sabkhas) (Schile-Beers et al. 2019). Among potential blue carbon ecosystems, macroalgal beds are gaining recognition (e.g., Froehlich et al. 2019; Krause-Jensen and Duarte 2016; Krause-Jensen et al. 2018; Lovelock and Duarte 2019; Ortega et al. 2019; Queirós et al. 2019; Watanabe et al. 2020). Although global estimates of atmospheric $\mathrm{CO}_{2}$ uptake rates by macroalgal beds are few and extremely uncertain, estimates of the global annual $\mathrm{CO}_{2}$ gas exchange rate indicate that among global shallow coastal ecosystems macroalgal beds may be the largest contributor to the net $\mathrm{CO}_{2}$ uptake rate (Fig. 22.4). 
(a)

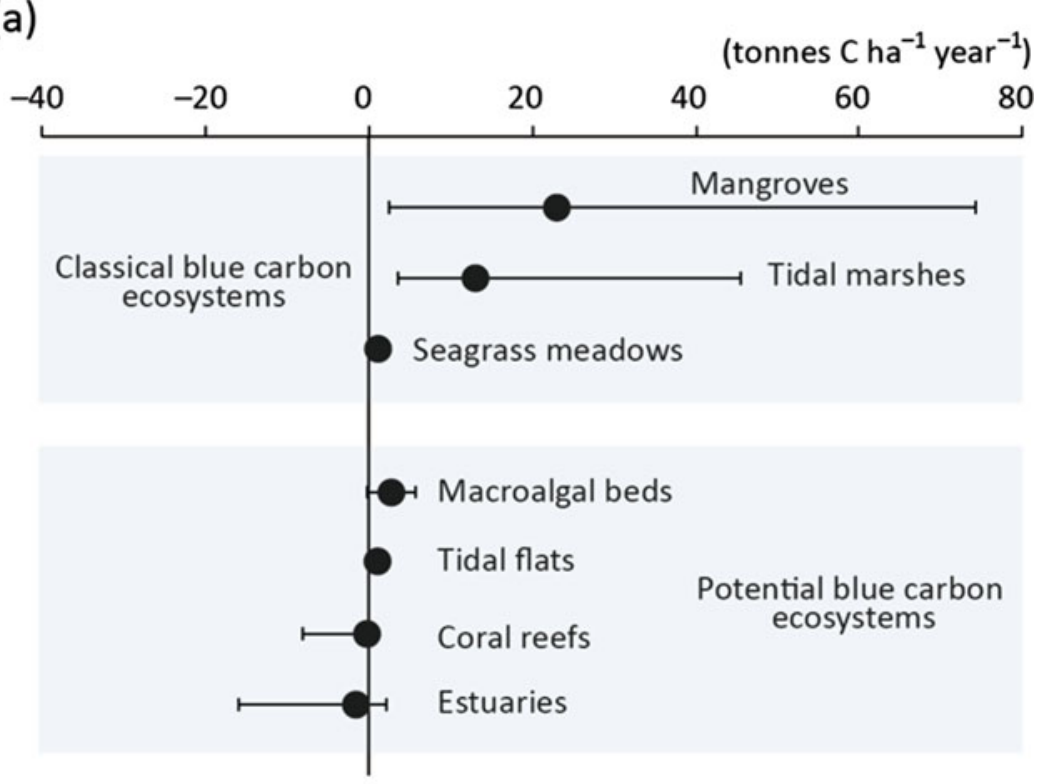

(b)

(million tonnes $\mathrm{C}$ year ${ }^{-1}$ )

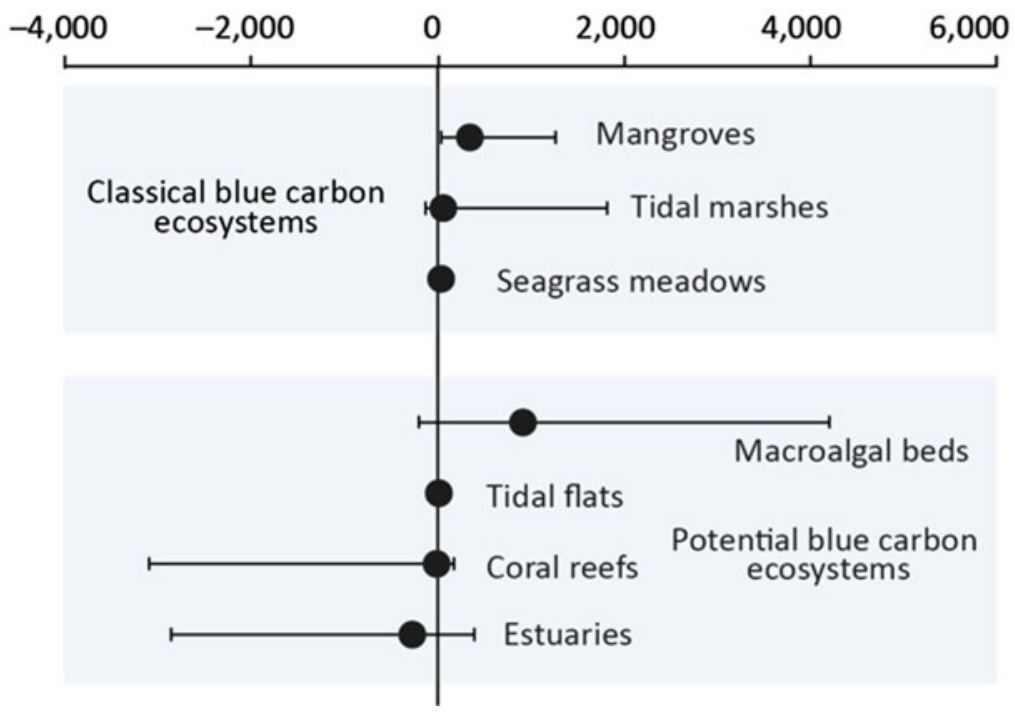

Fig. 22.4 Global annual $\mathrm{CO}_{2}$ gas exchange rates (a) per unit area and (b) on a global basis (modified from Kuwae and Hori 2019). Positive values indicate the uptake of atmospheric $\mathrm{CO}_{2}$. Bars indicate maximum and minimum values 


\subsubsection{Considering Co-benefits}

Although this chapter focused on the specific ecosystem service of climate regulation, SCEs provide various ecosystem services and thus represent natural capital. It is important to manage this natural capital to take advantage of co-benefits such as food provision, recreation, environmental purification, health, and employment creation and to contribute to food security, ecosystem integrity, and biodiversity (Okada et al. 2019). However, highlighting climate change countermeasures, in which society is becoming increasingly interested and concerned, can help to initiate or accelerate the conservation and restoration of SCEs.

\subsubsection{Monetizing and Crediting Co-benefits}

Ensuring that the effectiveness and importance of SCEs are widely perceived and understood by the various coastal stakeholders, researchers, engineers, and economists is of first importance when quantifying SCE functions and monetizing, and ideally crediting, the full range of the provided benefits (Okada et al. 2021). Even if practitioners perceive SCEs to be cost-effective and to have an acceptable internal rate of return, the lack of quantitative evidence of the benefits of SCEs may discourage planners, policy-makers, and investors from deciding to implement or invest in blue carbon projects (Emerton 2013).

When considering the cost-effectiveness of SCEs, it is preferable to first quantify all of their functions and to consider trade-offs among them and then to monetize them according to the results they produce, rather than to base the monetization of the benefits of SCEs on willingness to pay as determined by questionnaire surveys. Function-based monetization, which involves the direct evaluation of multifunctionality supported by numerical evidence, is more likely to satisfy coastal stakeholders and to help secure public financing or attract funds from private companies and investors (Vanderklift et al. 2019).

For most projects, there is strong pressure not to waste money, and projects that are highly uncertain or have a high risk of failure from the perspective of cost-effectiveness are unlikely to be approved by decision-makers (Hinkel et al. 2014, 2018). Risk-taking decision-making is difficult not only in the case of public works projects but also in the case of investor-financed pro-environmental activities undertaken by private companies and through private donations. Hence, risk exposure must be reduced by improving the cost-effectiveness of projects. 


\subsubsection{Challenges to Expanding Credit Trading}

Although the quantitative social impact of blue carbon offset credits is minimal at this time, given the potential of blue carbon for mitigating climate change, expanding the volume and enhancing the social impact of credit trading are important (Fig. 22.1). Some future challenges to be addressed are listed below.

First, it is necessary to further improve the motivation of both credit creators and buyers. For example, the Japanese government has set a goal to account for blue carbon in the national inventory by 2024. Making blue carbon offset credit schemes that contribute directly to such a national indicator is expected to improve the motivation of credit creators. In addition, for credit buyers, being able to reflect the blue carbon credits they offset in the NDCs of the Paris Agreement will enable them to contribute directly to the international community's goals and motivate them to contribute to not only their own corporate social responsibility (CSR) but also their ESG indicators.

Second, it is necessary to enhance offset credit transaction products to generate interest by more participants. One idea to increase the number of participants is to present an array of trading products by assessing the economic value of cobenefits and allowing them to be traded together with carbon. By doing so, credit creators can expect to increase their sales proceeds by increasing both the unit price and transaction volume. In turn, credit buyers would be motivated by the ability to choose trading products that better fit their goals and branding messages.

Third, increasing the number of demonstration projects, such as the project promoted by JBE in collaboration with the Japanese government and the collaboration with local government promoted by the City of Yokohama, and accumulating good practices will contribute to raising awareness and interest in the blue carbon offsetting, which will in turn motivate participants.

Finally, we should not forget the role of the credit secretariat, which mediates transactions. At present, because the amount of blue carbon credits being traded worldwide is low, it is difficult to maintain the system in a stable and sustainable manner with the income from intermediary fees. Increasing the trading volume and the unit price by increasing the number of participants and motivating them to participate in the credit system is thus important for the smooth operation of the secretariat. In addition, a system such as a validation and verification body (VVB), which is independent of the credit secretariat as established by JBE, is important to ensure the credibility of the system through enhanced validation and verification. This credibility is essential to increase the number of participants in the credit system. 


\section{References}

Abo K, Sugimatsu K, Hori M, Yoshida G, Shimabukuro H, Yagi H, Nakayama A, Tarutani K (2019) Quantifying the fate of captured carbon: from seagrass meadow to deep sea. In: Kuwae T, Hori M (eds) Blue carbon in shallow coastal ecosystems: carbon dynamics, policy, and implementation. Springer, Singapore, pp 251-271

Arias-Ortiz A, Serrano O, Masqué P et al (2018) A marine heatwave drives massive losses from the world's largest seagrass carbon stocks. Nat Clim Chang 8:338-344

Atwood TB, Connolly RM, Ritchie EG et al (2015) Predators help protect carbon stocks in blue carbon ecosystems. Nat Clim Chang 5:1038-1045

Atwood TB, Connolly RM, Almahasheer H et al (2017) Global patterns in mangrove soil carbon stocks and losses. Nat Clim Chang 7:523-528

Burden A, Garbutt RA, Evans CD et al (2013) Carbon sequestration and biogeochemical cycling in a saltmarsh subject to coastal managed realignment. Estuar Coast Shelf Sci 120:12-20

Cahoon DR, Hensel P, Rybczyk J et al (2003) Mass tree mortality leads to mangrove peat collapse at Bay Islands, Honduras, after Hurricane Mitch. J Ecol 91:1093-1105

Craft C, Megonigal P, Broome S et al (2003) The pace of ecosystem development of constructed Spartina alterniflora marshes. Ecol Appl 13:1417-1432

Crooks S, Herr D, Tamelander J, Laffoley D, Vandever J (2011) Mitigating climate change through restoration and management of coastal wetlands and near-shore marine ecosystems: challenges and opportunities. https://www.uncclearn.org/sites/default/files/inventory/wb87.pdf

Crooks S, Emmer I, Murdiyarso D, Brown B (2014) Guiding principles for delivering coastal wetland carbon projects. Report to the United Nations Environment Program and the Center for International Forestry Research. http://www.cifor.org/publications/pdf_files/Books/ BMurdiyarso1402.pdf

Crooks S, Sutton-Grier AE, Troxler TG, Herold N, Bernal B, Schile-Beers L, Wirth T (2018) Coastal wetland management as a contribution to the US National Greenhouse Gas Inventory. Nat Clim Chang 8:1109-1112

Crooks S, Windham-Myers L, Troxler TG (2019) Defining blue carbon: the emergence of climate context for coastal carbon dynamics. In: Windham-Myers L, Crooks S, Troxler TG (eds) A blue carbon primer: the state of coastal wetland carbon science, practice and policy. CRC Press, Boca Raton, pp 1-8

Crosswell JR, Anderson IC, Stanhope JW et al (2017) Carbon budget of a shallow, lagoonal estuary: transformations and source-sink dynamics along the river-estuary-ocean continuum. Limnol Oceanogr 62:S29-S45

Duarte CM, Krause-Jensen D (2017) Export from seagrass meadows contributes to marine carbon sequestration. Front Mar Sci 4:13

Duarte CM, Losada IJ, Hendriks IE, Mazarrasa I, Marbà N (2013) The role of coastal plant communities for climate change mitigation and adaptation. Nat Clim Chang 3:961-968

Duarte CM, Agusti S, Barbier E et al (2020) Rebuilding marine life. Nature 580:39-51

Emerton L (2013) Using valuation to make the case for economic incentives: promoting investments in marine and coastal ecosystems as development infrastructure. In: Essam M (ed) Economic incentives for marine and coastal conservation: prospects, challenges and policy implications. Earthscan Press, London

EX-ACT (2017) EX-ante carbon balance tool, blue carbon and fisheries. Food and Agriculture Organization. http://www.fao.org/3/a-i8342e.pdf

Friedlingstein P et al (2020) Global Carbon Budget 2020. Earth Syst Sci Data 12:3269-3340

Froehlich HE, Afflerbach JC, Frazier M, Halpern BS (2019) Blue growth potential to mitigate climate change through seaweed offsetting. Curr Biol 29:3087-3093

Greiner JT, McGlathery KJ, Gunnell J, McKee BA (2013) Seagrass restoration enhances "blue carbon" sequestration in coastal waters. PLoS One 8:e72469 
Hamaguchi M, Shimabukuro H, Hori M, Yoshida G, Terada T, Miyajima T (2018) Quantitative real-time polymerase chain reaction (PCR) and droplet digital PCR duplex assays for detecting Zostera marina DNA in coastal sediments. Limnol Oceanogr Method 16:253-264

Herr D, Landis E (2016) Coastal blue carbon ecosystems. Opportunities for nationally determined contributions: policy brief. IUCN, Gland; The Nature Conservancy, Washington, DC

Herr DT, Agardy D, Benzaken F et al (2015) Coastal "blue" carbon: a revised guide to supporting coastal wetland programs and projects using climate finance and other financial mechanisms. IUCN, Gland. https://doi.org/10.2305/IUCN.CH.2015.10.en

Hill R, Bellgrove A, Macreadie PI et al (2015) Can macroalgae contribute to blue carbon? An Australian perspective. Limnol Oceanogr 60:1689-1706

Hinkel J, Lincke D, Vafeidis AT et al (2014) Coastal flood damage and adaptation costs under 21st century sea-level rise. Proc Natl Acad Sci U S A 111:3292-3297

Hinkel J et al (2018) The ability of societies to adapt to twenty-first-century sea-level rise. Nat Clim Chang 8:570-578

Hoegh-Guldberg O, Northrop E, Lubchenco J (2019) The ocean is key to achieving climate and societal goals. Science 365:1372-1374

Howard J, Hoyt S, Isensee K, Pidgeon E, Telszewski M (2014) Coastal blue carbon: methods for assessing carbon stocks and emissions factors in mangroves, tidal salt marshes, and seagrass meadows. Conservation International, Intergovernmental Oceanographic Commission of UNESCO, International Union for Conservation of Nature, Arlington, Virginia

Howard J, McLeod E, Thomas S et al (2017) The potential to integrate blue carbon into MPA design and management. Aquat Conserv Mar Freshwat Ecosyst 27(S1):100-115

IPCC (2013) Fifth assessment report of the intergovernmental panel on climate change. IPCC, Geneva

IPCC (2014) In: Hiraishi T, Krug T, Tanabe K et al (eds) 2013 supplement to the 2006 IPCC guidelines for national greenhouse gas inventories: wetlands. IPCC, Geneva

Jiao N, Wang H, Xu G, Aricò S (2018) Blue carbon on the rise: challenges and opportunities. Natl Sci Rev 5:464-468

Kauffman BJ, Arifanti VB, Trejo HH et al (2017) The jumbo carbon footprint of a shrimp: carbon losses from mangrove deforestation. Front Ecol Environ 15:183-188

Kelleway J, Serrano O, Cannard T et al (2017) Technical review of opportunities for including blue carbon in the Australian Government's emissions reduction fund. CSIRO, Canberra

Kelleway JJ et al (2020) A national approach to greenhouse gas abatement through blue carbon management. Glob Environ Chang 63:102083

Krause-Jensen D, Duarte CM (2016) Substantial role of macroalgae in marine carbon sequestration. Nat Geosci 9:737-742

Krause-Jensen D, Lavery P, Serrano O, Marbà N, Masque P, Duarte CM (2018) Sequestration of macroalgal carbon: the elephant in the blue carbon room. Biol Lett 14:20180236

Kuwae T, Crooks S (2021) Linking climate change mitigation and adaptation through coastal green-gray infrastructure: a perspective. Coast Eng J 63:188-199

Kuwae T, Hori M (2019) Blue carbon in shallow coastal ecosystems. Springer, Singapore, $373 \mathrm{p}$

Kuwae T, Kanda J, Kubo A et al (2016) Blue carbon in human-dominated estuarine and shallow coastal systems. Ambio 45:290-301

Kuwae T, Yoshida G, Hori M, Watanabe K, Tanaya T, Okada T, Umezawa Y, Sasaki J (2019) Nationwide estimation of the annual uptake of atmospheric carbon dioxide by shallow coastal ecosystems in Japan. J Jpn Soc Civil Eng B2 75:10-20

Laffoley DA, Grimsditch G (2009) The management of natural coastal carbon sinks. IUCN, Gland, 53 pp. https://portals.iucn.org/library/sites/library/files/documents/2009-038.pdf

Lovelock CE, Duarte CM (2019) Dimensions of blue carbon and emerging perspectives. Biol Lett 15:20180781

Lovelock CE, Atwood T, Baldock J et al (2017) Assessing the risk of carbon dioxide emissions from blue carbon ecosystems. Front Ecol Environ 15:257-265 
Lutz SJ, Neumann C, Bredbenner A (2014) Building blue carbon projects: an introductory guide. https://gridarendal-website-live.s3.amazonaws.com/production/documents/:s_document/317/ original/building_blue_carbon_projectsLowRes.pdf?1489067674

Macreadie PI, Trevathan-Tackett SM, Skilbeck CG et al (2015) Losses and recovery of organic carbon from a seagrass ecosystem following disturbance. Proc R Soc B Biol Sci 282:1-6

Macreadie PI et al (2019) The future of blue carbon science. Nat Commun 10:3998

Marbà N, Arias-Ortiz A, Masqué P, Kendrick GA, Mazarrasa I, Bastyan GR, Garcia-Orellana J, Duarte CM (2015) Impact of seagrass loss and subsequent revegetation on carbon sequestration and stocks. J Ecol 103:296-302

Martin A, Landis E, Bryson C, Lynaugh S, Mongeau A, Lutz S (2016) Blue carbon: nationally determined contributions inventory. Appendix to: coastal blue carbon ecosystems: opportunities for nationally determined contributions. GRID, Arendal, Norway

MLIT (2020) Ministry of land, infrastructure, transport and tourism. https://www.mlit.go.jp/report/ press/port06_hh_000216.html

Murray BC, Pendleton L, Jenkins WA, Sifleet S (2011) Green payments for blue carbon: economic incentives for protecting threatened coastal habitats. Nicholas Institute for Environmental Policy Solutions, Report NI, 11(04). https://nicholasinstitute.duke.edu/sites/default/ files/publications/blue-carbon-report-paper.pdf

Nellemann C, Corcoran E, Duarte CM, et al (2009) Blue Carbon: a rapid response assessment. United Nations Environmental Programme, GRID-Arendal, Birkeland Trykkeri AS, Birkeland

Nobutoki M, Yoshihara S, Kuwae T (2019) Carbon offset utilizing coastal waters: Yokohama blue carbon project. In: Kuwae T, Hori M (eds) Blue carbon in shallow coastal ecosystems. Springer, Singapore

O'Connor JJ, Fest BJ, Sievers M, Swearer SE (2020) Impacts of land management practices on blue carbon stocks and greenhouse gas fluxes in coastal ecosystems- a meta-analysis. Glob Chang Biol 26:1354-1366

Okada $\mathrm{T}$ et al (2019) Method for the quantitative evaluation of ecosystem services in coastal regions. PeerJ 6:e6234

Okada T, Mito Y, Akiyama YB et al (2021) Green port structures and their ecosystem services in highly urbanized bay. Jpn Cost Eng J. https://doi.org/10.1080/21664250.2021.1911194

Orr KK (2014) Floating seaweed (Sargassum). In: Laffoley D, Baxter JM, Thevenon F, Oliver J (eds) The significance and management of natural carbon stores in the open ocean. Full report. IUCN, Gland, pp 55-67

Ortega A, Geraldi NR, Alam I et al (2019) Important contribution of macroalgae to oceanic carbon sequestration. Nat Geosci 12:748-754

Osland MJ, Spivak AC, Nestlerode J et al (2012) Ecosystem development after mangrove wetland creation: plant-soil change across a 20-year chronosequence. Ecosystems 15:848-866

Queirós AM et al (2019) Connected macroalgal-sediment systems: blue carbon and food webs in the deep coastal ocean. Ecol Monogr 89:e1366

Salmo SG, Lovelock CE, Duke NC (2013) Vegetation and soil characteristics as indicators of restoration trajectories in restored mangroves. Hydrobiology 720:1-18

Sapkota Y, White JR (2020) Carbon offset market methodologies applicable for coastal wetland restoration and conservation in the United States: a review. Sci Total Environ 701:134497

Schile-Beers L et al (2019) Carbon sequestration in arid blue carbon ecosystems: a case study from the United Arab Emirates. In: Windham-Myers L, Crooks S, Troxler TG (eds) A blue carbon primer: the state of coastal wetland carbon science, practice and policy. CRC Press, Boca Raton, pp 327-339

Serrano O, Ruhon R, Lavery PS et al (2016) Impact of mooring activities on carbon stocks in seagrass meadows. Sci Rep 6:23193

Suehiro F, Suzuki H, Yoshihara S, Shuji Okazaki S (2020) Study on the world's first credit certification for bule carbon in eelgrass fields in Yokohama City. J Jpn Soc Civil Eng G3:49-53

Sugimura Y, Kobayashi T, Mito Y, Yoshihara S, Okada T, Kuwae T (2021) The establishment and future prospects of blue carbon offset system at Hakata Port. J Jpn Soc Civil Eng 77:31-48 
Sutton-Grier AE, Wowk K, Bamford H (2015) Future of our coasts: the potential for natural and hybrid infrastructure to enhance the resilience of our coastal communities, economies and ecosystems. Environ Sci Pol 51:137-148

Thomas S (2014) Blue carbon: knowledge gaps, critical issues, and novel approaches. Ecol Econ 107:22-38

Tokoro T, Watanabe K, Tada K, Kuwae T (2015) Guideline of blue carbon $\left(\mathrm{CO}_{2}\right.$ absorption and carbon sequestration) measurement methodology in port areas. Technical note of the port and airport research institute no 1309

Vanderklift MA et al (2019) Constraints and opportunities for market-based finance for the restoration and protection of blue carbon ecosystems. Mar Policy 107:103429

Verified Carbon Standard (2015) Methodology for tidal wetland and seagrass restoration. http:// www.v-c-s.org/methodologies/methodology-tidal-wetland-and-seagrass-restoration-v10

Villa JA, Bernal B (2018) Carbon sequestration in wetlands, from science to practice: an overview of the biogeochemical process, measurement methods, and policy framework. Ecol Eng 114:115-128

Wada S, Aoki MN, Mikami A et al (2008) Bioavailability of macroalgal dissolved organic matter in seawater. Mar Ecol Prog Ser 370:33-44

Watanabe K, Seike K, Kajihara R, Montani S, Kuwae T (2019) Relative sea-level change regulates organic carbon accumulation in coastal habitats. Glob Chang Biol 25:1063-1077

Watanabe K, Yoshida G, Hori M, Umezawa Y, Moki H, Kuwae T (2020) Macroalgal metabolism and lateral carbon flows can create significant carbon sinks. Biogeosciences 17:2425-2440

World Bank (2017) Implementing nature based flood protection: principles and implementation guidance. http://documents.worldbank.org/curated/en/739421509427698706/Implementingnature-based-flood-protection-principles-and-implementation-guidance

Wylie L, Sutton-Grier AE, Moore A (2016) Keys to successful blue carbon projects: lessons learned from global case studies. Mar Policy 65:76-84

Wyndham-Meyers L, Crooks S, Troxler T (2018) A blue carbon primer: the state of coastal wetland carbon science, practice and policy. CRC Taylor and Francis, Boca Raton, $352 \mathrm{p}$

Open Access This chapter is licensed under the terms of the Creative Commons Attribution 4.0 International License (http://creativecommons.org/licenses/by/4.0/), which permits use, sharing, adaptation, distribution and reproduction in any medium or format, as long as you give appropriate credit to the original author(s) and the source, provide a link to the Creative Commons license and indicate if changes were made.

The images or other third party material in this chapter are included in the chapter's Creative Commons license, unless indicated otherwise in a credit line to the material. If material is not included in the chapter's Creative Commons license and your intended use is not permitted by statutory regulation or exceeds the permitted use, you will need to obtain permission directly from the copyright holder. 